\title{
Jan Tinbergen: Engineering a Better World
}

\section{Celebrating Fifty Years of Nobel Prizes in Economics}

\author{
Ben J. Heijdra ${ }^{1} \cdot$ Bas ter Weel ${ }^{2,3}$ \\ Published online: 27 August 2019 \\ (c) Springer Science+Business Media, LLC, part of Springer Nature 2019
}

In 1969 Jan Tinbergen was awarded the first Nobel Prize in Economic Sciences by the Swedish Central Bank, together with Ragnar Frisch. De Economist devotes a commemorative issue on the occasion of the fiftieth anniversary of the Nobel Prize in Economic Sciences emphasizing the contributions of Jan Tinbergen to the profession. ${ }^{1}$ The journal has benefited from Tinbergen's work as a member of the editorial board (1946-1988) and has published nearly forty of his articles. Most of these articles relate directly to the areas of research to which Tinbergen has made original contributions (e.g., Kol 2004 for an overview). His first article in De Economist 'Over de mathematies-statistiese methoden voor konjunktuuronderzoek' (On the mathematical-statistical methods of business-cycle research) was published in 1927 (Tinbergen 1927), and his last full article, which appeared more than 60 years later, was on 'The velocity of integration' (Tinbergen 1991).

This celebratory issue of De Economist consists of five papers. The first contribution has been written by Weinberg and Galenson (2019). They analyse the nature of the contributions of Nobel prize winners in economics by focussing on the lifecycle of laureates. Two polar types are characterised: conceptual innovators who conduct most of their innovative work early on and experimental innovators who build their contributions on accumulated experience. These polar types of researchers are developed in previous work by studying artists (such as painters and poets) and samples of scientists (e.g., Galenson and Weinberg 2000). It turns out that successful conceptual artists and scientists have set explicit goals they want to reach with their work. They set up a plan in advance and execute that plan with precision. Also, their contributions are radical and lead to new waves of thinking in the profession and

\footnotetext{
1 In 2004 a commemorative issue of De Economist was devoted to Tinbergen's 100th birthday in 2003 (see Cornelisse et al. 2004).

Bas ter Weel

B.terWeel@seo.nl

1 Faculty of Economics and Business, University of Groningen, Groningen, The Netherlands

2 SEO Amsterdam Economics, Amsterdam, The Netherlands

3 Amsterdam School of Economics, University of Amsterdam, Amsterdam, The Netherlands
} 
to new standards which new work has to meet and will be evaluated upon. Tinbergen's earlier work on business cycles and econometric modelling falls in this first category. His innovations were based on a clear plan to apply methods from physics to economic problems. Needless to say, the econometric approach to studying economic problems was a major innovation on which many scholars have subsequently built their work and careers-such as future Nobel laurates (e.g., Lawrence Klein and Christopher Sims). The other side of the spectrum is characterised by experimental innovators who are ambitious but conduct research and present work that is (mathematically) less precise. They apply a work process that is determined by trial and error. They arrive incrementally at their major contributions, which takes a long period of time. As a result, their major contributions arrive only later in their professional life cycle and are often based on accumulated experience. Tinbergen's work has also features of this way of working, which leads Weinberg and Galenson to conclude that he is close to the middle of the spectrum of their sample of Nobel laureates.

One of Tinbergen's more experimental contributions is about the income distribution, and specifically about the race between education (supply) and technology (demand). In his book on income inequality, Tinbergen (1975) analysed the race between labour demand and supply in determining the evolution of wages and inequality. ${ }^{2}$ Since the 1970 s, the demand side of the labour market is characterised by what is now called skill-biased technological change which favours higher skilled workers relative to lower skilled workers and which increases the wage premium (i.e., the returns to years of education). The supply side is characterised by a surge in the (relative) number of higher educated workers. Together it seems to be the case that supply is not able to catch up with demand, leading to higher levels of wage inequality in many countries.

James Heckman discusses Tinbergen's contribution to the theoretical and empirical literature on wage inequality in the second article of this issue (Heckman 2019). Tinbergen's model of heterogeneous workers who supply skill bundles to the market and who are matched to heterogeneous (demands by) firms was pioneering at the time and inspired subsequent hedonic models of skill prices. By changing the prices of components of these bundles of skills, Tinbergen was able to document the impact of technological change (from the demand side) and of changes in the composition of labour supply (due to higher levels of acquired education by young workers). A main contribution of his approach is that the labour-market equilibrium is determined by the utility of workers and the technology of the firms who have to make wages and profits above a certain threshold to decide to participate. Because of the heterogeneous character of both workers and firms, they are matched according to a price function consistent with supply and demand in the market. In terms of empirical applications Tinbergen's work has been inspiring new research on documenting and interpreting trends in wage inequality. Task models, developed and reviewed by Acemoglu and Autor (2011), and work on the race between technology

\footnotetext{
2 Almost 20 years before publishing the book on inequality, Tinbergen published an article summarising the main ideas (Tinbergen 1956).
} 
and education (Goldin and Katz 2009) are based on his ideas. Tinbergen's contributions are developed further in recent decades as a result of more and better data and new insight in the determinants of inequality. For example, the dynamics of skill formation and the malleability of skills from young ages onward that seem to shape inequality are relatively young research lines that build on his fundamental insights (Cunha and Heckman 2007). Also more fundamental research on the identification and estimation of hedonic models is inspired by Tinbergen's ideas (Rosen 1974; Ekeland et al. 2004).

Heckman concludes his review of Tinbergen's work on the race between labour demand and supply by asking the question why his work has been overlooked or at least did not receive as much attention in the academic literature as it should have. One of his answers is that Tinbergen viewed his research as an input to designing effective planning policies, an unpopular way of vending academic research but much in line with an engineering approach to signalling and solving social problems. In a third paper, Don (2019) shows that the motivation of much of his early work indeed was initiated by a strong desire to improve economic policies and that planning was an important part of this desire.

Don's contribution assesses what influence Jan Tinbergen has had on Dutch economic policy in the 1930s and 1940s, with a focus on macroeconomic policy. The conclusion of the analysis is that his direct influence has been limited. The main reason seems to be that there was at the time no political and policy infrastructure or environment in which his economic approach to policymaking was appreciated. Nevertheless, the development of his macroeconomic model in the mid-1930s was a major step forward for the economics profession and for his own research and policy agenda. After the Second World War the Central Planning Bureau (CPB) was established to write a general social economic-financial plan, which would contain guidelines for government policy. ${ }^{3}$ Tinbergen became its first director, but in the first years of the CPB there was not much direct influence of Tinbergen or the CPB on Dutch economic policy. More indirectly, the assessments of the economic prospects and of various policy alternatives slowly received more attention from the ministers responsible for economic policy. In the 1950s with the establishment of other institutions his influence on Dutch economic policymaking increased. Overall, Don concludes that Tinbergen's efforts to make an impact on policymaking have been an important force in establishing and guiding the Dutch consensus economy that characterised the second half of the twentieth century.

Of all contributors to this issue Morgan (2019) is perhaps in the best position to write about Tinbergen's contributions to the economics profession. Indeed, together with Jan Magnus she conducted and published a long interview with Tinbergen in the mid-1980s (Magnus and Morgan 1987). Paraphrasing the current U.S. President somewhat, Tinbergen's approach to economics is best captured by the slogan 'Let's make economics useful to mankind'. Morgan argues that Tinbergen's most important contributions in the period 1940-1960 are the development of the first

\footnotetext{
3 The CPB is now known as the Netherlands Bureau for Economic Policy Analysis. It serves as an independent think tank for the Dutch government.
} 
macro-econometric models and the creation of the theory of economic policy. Tinbergen viewed his pioneering macro-econometric models as examples of 'quantitatively stylizing' business cycles: the economic engineer builds and tests a small stylized representation of a much more complex world. Morgan argues that of all academic economists around at the time, the young Tinbergen was really the only person able to bring these modelling projects to the right level. She refers to 'Recovering Tinbergen' but also argues that there may be many forgotten contributions and ideas that just need to be 'rediscovered' in the near future. One of these ideas is Tinbergen's view on the way in which we should incorporate the environment in economic decision-making, an issue at the forefront of the current debate on mitigating the effects of climate change by effective policy instruments.

In the final contribution to this issue De Zeeuw (2019) reviews Tinbergen's views on environmental policies. Along with poverty and war, Tinbergen saw environmental change and pollution as one of the main problems facing the world. In this he was surely one of the earliest economists to do so. Tinbergen published two monographs on environmental issues but, since they were written in Dutch, these are not well-known to the academic and policy community outside of the Netherlands. In Tinbergen et al. (1976) he reacts (in English) to the doomsday messages of the Club of Rome. In his contribution, De Zeeuw succinctly summarises and discusses Tinbergen's views on environmental policies. Not surprisingly, the economic engineer did not see environmental issues as separate from poverty and economic development. Alleviating poverty requires economic growth but growth puts pressure on the natural environment. This dilemma is still with us today, but Tinbergen had already tolled the bell half a century ago. In his second monograph, published in 1987, Tinbergen extended his theory of economic policy (see also Morgan 2019, in this issue) to environmental issues: what are the problems, which are the targets, and what are the instruments? In a more accessible source, Tinbergen and Fischer (1987) make a powerful plea for radical system reform. Supra-national institutions should be formed with for example the new IMF acting as the world's Ministry of Finance, and a redesigned Word Bank acting as the global Central Bank responsible for monetary policy, food production and distribution, energy provision, and the environment (de Wolff 1994, p. 105). Of course global cooperation is a difficult thing to achieve, Nevertheless, current environmental economists are able to benefit from Tinbergen's work. This could be another case for starting to 'rediscover' Jan Tinbergen's contributions to the economic profession in terms of theory and policy: 50 years ago he already forecasted which problems we would be facing today.

\section{References}

Acemoglu, D., \& Autor, D. H. (2011). Skills, tasks and technologies: Implications for employment and earnings. In O. C. Ashenfelter \& D. Card (Eds.), Handbook of labor economics (Vol. 4B, pp. 10431171). Amsterdam: Elsevier.

Cornelisse, P., van Dijk, H., \& Don, H. (2004). Introduction to the Tinbergen centennial issue. De Economist, 152(2), 161-165. 
Cunha, F., \& Heckman, J. J. (2007). The technology of skill formation. American Economic Review, 97(2), 31-47.

de Wolff, P. (1994). Levensbericht-Jan Tinbergen. In Levensberichten en herdenkingen (Life report and commemorations) (pp. 97-106). Huygens Institute, Amsterdam: Royal Netherlands Academy of Arts and Sciences.

de Zeeuw, A. (2019). Jan Tinbergen, from mathematics to poverty and environment. De Economist. https:// doi.org/10.1007/s10645-019-09334-0.

Don, F. J. H. (2019). The influence of Jan Tinbergen on Dutch economic policy. De Economist. https:// doi.org/10.1007/s10645-019-09333-1.

Ekeland, I., Heckman, J. J., \& Nesheim, L. (2004). Identification and estimation of hedonic models. Journal of Political Economy, 112(S1), S60-S109.

Galenson, D. W., \& Weinberg, B. A. (2000). Age and the quality of work: The case of modern American painters. Journal of Political Economy, 108(4), 761-777.

Goldin, C. D., \& Katz, L. F. (2009). The race between education and technology. Cambridge: Harvard University Press.

Heckman, J. J. (2019). The race between demand and supply: Tinbergen's pioneering studies of earnings inequality. De Economist. https://doi.org/10.1007/s10645-019-09341-1.

Kol, J. (2004). Tinbergen in De Economist. De Economist, 152(2), 273-296.

Magnus, J., \& Morgan, M. S. (1987). The ET interview-J. Tinbergen. Econometric Theory, 3(1), $117-142$.

Morgan, M.S. (2019). Recovering Tinbergen. De Economist. https://doi.org/10.1007/s10645-019-09346-w.

Rosen, S. (1974). Hedonic prices and implicit markets: Product differentiation in pure competition. Journal of Political Economy, 82(1), 34-55.

Tinbergen, J. (1927). Over de mathematies-statistiese methoden voor konjunktuuronderzoek (On the mathematical-statistical methods for business-cycle research). De Economist, 76(1), 711-723.

Tinbergen, J. (1956). On the theory of income distribution. Weltwirtschaftliches Archiv, 77(1), 155-173.

Tinbergen, J. (1975). Income distribution: Analysis and policies. New York: North-Holland Publishing Company.

Tinbergen, J. (1991). The velocity of integration. De Economist, 139(1), 1-11.

Tinbergen, J., \& Fischer, D. (1987). Warfare and welfare: Integrating security policy into socio-economic policy. New York: St. Martin's Press.

Tinbergen, J., et al. (1976). Reshaping the international order: A report to the club of Rome. New York: E.P. Dutton.

Weinberg, B. A., \& Galenson, D. W. (2019). Creative careers: The life cycles of Nobel laureates in economics. De Economist. https://doi.org/10.1007/s10645-019-09339-9.

Publisher's Note Springer Nature remains neutral with regard to jurisdictional claims in published maps and institutional affiliations. 